\title{
NEW FIRM SURVIVAL IN DEVELOPING COUNTRIES: EVIDENCE FROM KOSOVO
}

\author{
SILVIANO ESTEVE-PÉREZ ${ }^{*}$ and FADIL SAHITI ${ }^{2}$ \\ ${ }^{1}$ Department of Applied Economics II, University of Valencia, Valencia, Spain; and \\ ${ }^{2}$ Department of Management, Rochester Institute of Technology, Prishtina, Kosovo
}

First version received March 2018; final version accepted December 2018

This paper examines both newborn firm survival and firm turnover in Kosovo using the population of new firms and registry information on active firms from 2008 to 2012. Survival analysis is employed to analyze the impact of firm- and industry-level characteristics on survival. We find that the hazard rate has an inverted U-shape relationship with both firm age and firm size. The risk of failure increases over the first two years and later decreases. In addition, firms with one employee and more than 10 employees enjoy better survival prospects than medium-sized companies. Interestingly, very large firms do not face fewer risks than very small companies. When compared to other developing countries, entry rates are lower but survival rates are higher. These features seem to be a distinctive characteristic of Kosovo.

Keywords: Firm survival; Churning; Developing countries; Survival analysis JEL classification: C41, L22, O12

\section{INTRODUCTION}

$\mathrm{U}$ NDERSTANDING the drivers of firm dynamics and specifically those factors that determine firm survival has attracted increasing attention from both researchers and policymakers. While there is an increasing body of literature that provides evidence on patterns of firm survival in developed economies, this evidence is relatively scarce for developing countries (Klapper and Richmond 2011). Most of the existing literature has focused on the manufacturing sector and developed countries (Ahn 2001; Scarpetta et al. 2002; Bartelsman, Haltiwanger, and Scarpetta 2009).

\footnotetext{
Silviano Esteve-Pérez acknowledges financial support from the Spanish Ministry of Science and Innovation (project RTI2018-100899-B-I00) and from the Valencian Regional Government (PROMETEO/2018/102). The usual disclaimer applies.

* Corresponding author: Silviano Esteve-Pérez, Department of Applied Economics II, Faculty of Economics, University of Valencia, Avenida de los Naranjos S/N, 46022 Valencia, Spain. Email: sesteve@uv.es
} 
The aim of this paper is to explore the survival patterns of firms that operate in a developing economy. It examines firm- and industry-level factors that shape the probability of firm survival for the entire population of 40,069 newborn firms in Kosovo from 2008 to 2012. To this end, this paper uses both nonparametric and semiparametric survival methods that focus on the determinants of the hazard rate, that is, the conditional probability of suffering an event (firm failure) at time $t$, provided the firm has survived up to that period. Furthermore, the paper also compares the patterns of firm churning in Kosovo, that is, entry and exit, to those found by previous studies for a number of OECD countries (e.g., Bartelsman, Haltiwanger, and Scarpetta 2009). This comparison is carried out using data on incumbents, entrants, and exiters provided by the Kosovo Business Registration Agency (KBRA) and tax administration (TA). ${ }^{1}$

Kosovo is a south-eastern European country with a population of 1.8 million inhabitants. Its per capita GDP significantly grew from US $\$ 1,088$ to US $\$ 3,641$ between 2000 and 2016. However, its economic growth has historically lagged behind that of neighboring countries. Thus, Kosovo's per capita income is one of the lowest in the region and it is included in the group of lower-middle-income economies. Its unemployment rate is above $40 \%$. $^{2}$ The size of the informal economy, the poor quality of its infrastructure and human capital, as well as the poor quality of institutions and regulations has led to an inadequate business environment that may hinder firm birth, growth, and survival, which may negatively affect productivity and economic growth (Sahiti and Smith 2017).

The main contribution of this paper is threefold. First, it explicitly explores factors that affect firm survival in a developing economy using a new dataset that comprises the entire population of newborn firms from 2008 to 2012. It is worth mentioning that we consider: (1) the entire population of newborn firms, rather than just a sample of them, (2) several cohorts of entrants, rather than just one, and (3) a developing and relatively young economy, which has so far been underexplored. Second, unlike the few previous studies of firm survival in lowincome countries that focus on the role of financial variables, this paper explores the impact of variables such as firm size, age, location, and legal structure on firm survival. Third, the combination of survival analysis and comparative study of firm churning unravels a number of distinctive features of industry dynamics in Kosovo with important policy implications.

This paper finds some striking differences in the firm survival patterns of Kosovo's firms when compared to other low-, medium-, and high-income countries. First, entry rates, especially of large firms, are remarkably lower than

1 Appendix provides the list of countries considered for comparison.

2 USAID, “USAID/Kosovo Strategic Plan 2010-2014.” May 20, 2010. https://pdf.usaid.gov/pdf _docs/PDACQ298.pdf. 
those in other developing countries. Second, newborn firms' chances of survival are higher than those in other developed and developing countries. Hence, churning is low. Third, the paper finds evidence of an inverted U-shaped relationship between the risk of firm exit and firm age and firm size. Very small and large firms face low failure rates. These results might suggest that unfavorable business environment factors (poor infrastructure, limited human capital, high levels of corruption, poor enforcement of regulations protecting investors, crime, high taxes, or high cost of finance) could discourage firm entry and exit (Klapper et al. 2007; Alam et al. 2008). In addition, poor economic prospects could push people into entrepreneurship and increase their chances of survival (Berner, Gomez, and Knorringa 2012).

The paper is organized as follows. Section II provides a brief overview of the related literature. Section III describes the data, and Section IV outlines the methods. Section V presents the results. Finally, Section VI discusses the results and concludes the paper.

\section{LITERATURE REVIEW}

The literature on firm entry and post-entry performance has long emphasized the association between firm age and firm size and survival performance. On the one hand, Stinchcombe (1965) points out the existence of a "liability of newness," that is, newly created firms suffer a greater risk of failure than their older counterparts. At entry, firms do not know if they have the necessary characteristics to adapt to the competitive environment and survive. As firms grow older, they learn about their fitness to survive. A large number of empirical studies find that the risk of firm failure falls with age (Mata and Portugal 1994; Geroski 1995; Bartelsman, Haltiwanger, and Scarpetta 2009). In contrast, the liability of "adolescence" hypothesis predicts that failure rates depict an inverted U-shaped relationship with age (Bruderl and Schussler 1990; Fichman and Levinthal 1991). New organizations can initially survive by drawing on their initial stock of endowments acquired at founding (e.g., venture capital funding and bank loans). Then, failure rates reach a peak with the exhaustion of the initial resources, and later decrease with only the fittest firms remain in the market. On the other hand, some studies find that small firms suffer a significantly higher risk of exit than their larger counterparts (Dunne, Roberts, and Samuelson 1988). Large firms are closer to the minimum efficient scale and have better access to external funds, and are also typically more diversified than smaller firms. In addition, larger firms may enjoy better organizational capabilities and managerial practices leading to the greater probability of survival (Audretsch and Mahmood 1994; Geroski, Mata, and Portugal 2010). 
Some authors examine the impact of legal and ownership structure on firm survival. According to Stiglitz and Weiss (1981) limited liability firms undertake projects with relatively higher expected returns but also higher risk of failure. The empirical evidence on the effect of foreign ownership on survival is inconclusive. Mata and Portugal (2002) initially find higher survival probabilities for foreign-owned companies than for domestic ones. Yet, once they control for other firm characteristics, such as size, share of qualified workers, and legal structure, the impact of foreign ownership on firm survival vanishes.

Furthermore, some studies find that survival rates differ across sectors (Audretsch and Mahmood 1994; Mata and Portugal 1994). The extent of economies of scale, the presence of cost advantages for incumbent firms, the growth rate of sector-specific demand, and the technological intensity of sectors may explain these differences.

Finally, spatial factors may also shape survival probabilities. Fotopoulos and Louri (2000) find that newborn firms located near metropolitan areas exhibit higher survival rates than those located elsewhere. This is related to some costand demand-side advantages of agglomeration (Dunne, Klimek, and Roberts 2005). Firms may benefit from larger demand in more populated areas. On the cost side, firms may take advantage of external economies arising from proximity of specialized suppliers, knowledge spillovers, and development of specialized labor markets. In contrast, more concentration may also lead to both fiercer competition between firms and congestion costs that may have a negative effect on firm survival. The empirical evidence reports a positive effect of agglomeration on survival, suggesting that positive effects on survival overcome the negative impact of tougher competition and congestion costs (Berglund and Brännäs 2001).

It is worth mentioning that most previous studies have investigated firm survival in developed economies. The evidence on developing economies is far scarcer. This paper attempts to fill this gap by examining firm survival in a young and developing economy.

\section{DATA}

The data used in this paper are drawn from two sources: (1) the KBRA and (2) TA. The first data source contains information about the population of newly established firms and follows them until the end of 2013. Hence, we can identify the birth and failure of all newborn firms over the period 2008-12. This dataset also includes some firm- and industry-level characteristics at birth. Subsection V-B applies survival analysis to the 40,069 newly created firms in Kosovo during 2008-12. Of these, 6,521 had exited the market by the end of 2013. 
The second dataset contains the list of all active firms in Kosovo over the period 2010-13. A firm is considered as active when it is included in the registry of the taxpayers and continues to pay taxes. Using information from TA and KBRA, Subsection V-A compares the patterns of firm churning in Kosovo over 2010-13 to those found by previous studies on firm demography for a number of OECD countries (Bartelsman, Haltiwanger, and Scarpetta 2009).

Despite the comprehensiveness of the data, some caveats must be considered. First, we cannot distinguish between different exit modes and routes: voluntary exit, bankruptcy, or ownership changes. However, the latter are relatively uncommon and do not involve a serious limitation. Second, the number of explanatory variables is reduced, and the only reliable measure of firm size is the number of employees.

\section{METHODS}

Survival methods are employed to evaluate the relationship between firm-, industry-, and regional-level characteristics and survival of newborn firms in Kosovo. These methods allow controlling for both the occurrence and timing of firm failure and appropriately handle right-censoring (i.e., firms that are alive at the end of the observation period). Also, they allow controlling for unobserved firm heterogeneity that may lead to biased inference.

The empirical analysis is carried out in two steps. First, we estimate KaplanMeier survival functions and test whether survival functions across groups of firms according to the different values of the explanatory variables are significantly different (Hosmer and Lemeshow 1999). The Kaplan-Meier estimator of the survivor function is:

$$
S(t)=\operatorname{Pr}(T \geq t)=\prod_{j \backslash t_{j} \leq t} \frac{n_{j}-d_{j}}{n_{j}},
$$

where $n_{j}$ is the number of firms "at risk" right before the $j$-th exit time, while the $d_{j}$ is the number of failures during that exit time.

Second, we estimate both continuous-time and discrete-time proportional hazard survival models to assess the relationship between each explanatory variable and the hazard rate, once we control for other variables. ${ }^{3}$ The dependent variable is the hazard rate $(h)$, that is, the probability of firm exit in a given period

3 See Jenkins (2005) for an excellent overview of continuous-time and discrete-time proportional hazard models. 
conditional on survival up to that period. We begin with the estimation of the following Cox proportional hazards model (Cox 1975):

$$
h_{i}(t)=h_{0}(t) \exp \left(\sum_{i=1}^{p} \beta_{i} X_{i}^{\prime}\right),
$$

where $h_{0}(t)$ is the baseline hazard and captures the common risk faced by all firms of a particular age (i.e., when $X_{i}=0$ ), which is left unspecified. In this model, the effect of each variable is a parallel constant shift in the baseline hazard, which is estimated for all those firms that survive up to a particular period. In the empirical specification, we further include year dummies to control for the overall evolution of risk over time (i.e., to control for the effect of business cycle). Parameters are consistently estimated by the partial likelihood method of estimation (Cox 1975).

Furthermore, this paper also estimates a discrete-time proportional hazard model. Although firm exit may occur at any instant, the dataset provides yearly information. Hence, survival times are grouped into discrete intervals of time of one year, and then we estimate a complementary log-log model (cloglog). By assuming that the discrete hazard rate follows a complementary log-log distribution (Prentice and Gloeckler 1978) and allowing for unobserved individual heterogeneity, the estimated equation takes the following form:

$$
\mathrm{c} \log \log \left[1-h_{j}(X \mid v)\right] \equiv \log \left(-\log \left[1-h_{j}(X \mid v)\right]\right)=\beta^{\prime} X+\gamma_{j}+u,
$$

where $\gamma_{j}$ is the interval baseline hazard and summarizes the pattern of duration dependence (i.e., firm age). We also incorporate firm-level random effects by means of an error term $u=\log (v)$ that is assumed to be normally distributed with zero mean and variance $\sigma^{2}$. This is the so-called frailty term and allows controlling for unobserved individual heterogeneity. In the empirical analysis, we test whether the variance of the frailty term is statistically different from zero: if this variance were not statistically different from zero, then a non-frailty model would be the preferred specification. To obtain efficient estimators and unbiased standard errors, we apply the Hubber-White sandwich or robust estimator.

\section{RESULTS}

This section reports and discusses our main results. Subsection V-A presents an international comparison of firm dynamics. Subsection V-B uses nonparametric and regression analysis to explore the association between newborn firms' characteristics and their survival prospects in Kosovo. 


\section{A. Firm Entry, Exit, and Survival in Kosovo: An International Comparison}

This section uses data from KBRA and TA from 2010 to 2013 in order to compare firm entry, exit, and survival rates ${ }^{4}$ in Kosovo with those of other countries (Bartelsman, Haltiwanger, and Scarpetta 2009). In addition, for comparison purposes, a simple average is also added (labeled as "AVERAGE"). A caveat of this analysis is that the comparison is carried out for different time periods. Data for Kosovo are only available for 2010-13 and, importantly, previous comparative studies also use different sample periods for different countries. Despite this shortcoming, the comparison is still meaningful given that it allows relating firm dynamics in Kosovo to the general patterns found for a number of heterogeneous countries with different income levels.

Figures 1 and 2 present entry and exit rates for firms with at least one employee and for those with more than 20 employees, respectively. We discuss the main findings in turn.

First, in all countries small-scale entry is more common than large-scale entry, which is in line with the findings in the literature (e.g., Geroski 1995). Indeed, differences in regulations according to firm size may explain this difference (Bartelsman, Haltiwanger, and Scarpetta 2009). In addition, the business environment in which firms operate may discourage large-firm entry, especially in lessdeveloped countries (Alam et al. 2008). ${ }^{5}$

Second, developed economies show relatively high churning, with little net entry. More developed countries have lower entry rates than lessdeveloped countries, including Kosovo. In contrast, exit rates are lower for the latter than for the former countries. This might also be related to the development stage of the economies, with some developing countries growing relatively fast and/or might suggest that market selection forces do not fully operate in some countries (e.g., Kosovo, Romania, Latvia, Hungary, and Slovenia).

Third, Kosovo shares some features with developing countries, such as high net entry rates due to their high entry rates and low exit rates, but has two remarkable differences with them. On the one hand, it shows the lowest exit rates for both size groups. On the other hand, entry rates are lower than in lessdeveloped economies, especially among large firms.

4 The entry rate is defined as the number of new firms divided by the total number of incumbent and entrant firms that are actively producing in a given year; the exit rate is defined as the number of firms exiting the market in a given year divided by the population of origin (i.e., the incumbents in the previous year). Survival rate for age $t$ is the share of firms that survive beyond $t$ periods.

5 Among others, business environment factors include poor infrastructure, limited human capital, high levels of corruption, crime, customs rate, high taxes, or high cost of finance. 
Fig. 1. Entry and Exit Rates of Firms with at Least One Employee

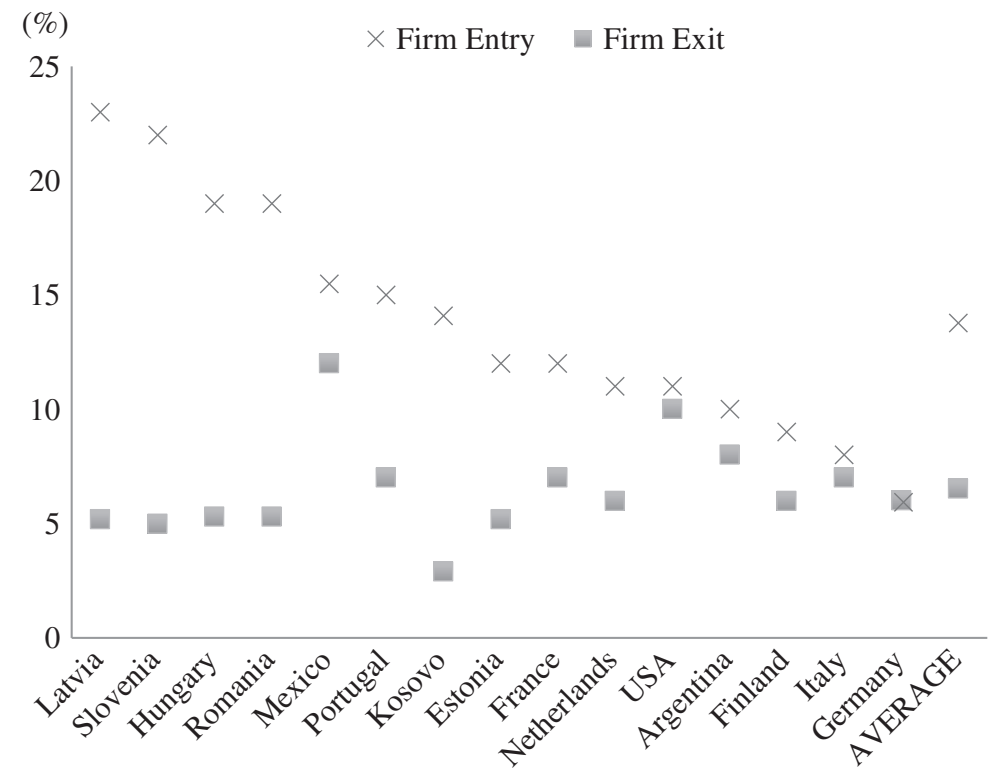

Source: Authors' calculations using data from KBRA for Kosovo, and Bartelsman, Haltiwanger, and Scarpetta (2009) for all other countries. Countries are sorted in descending order by firm entry. AVERAGE is the simple average.

Fig. 2. Entry and Exit Rates of Firms with 20 or More Employees

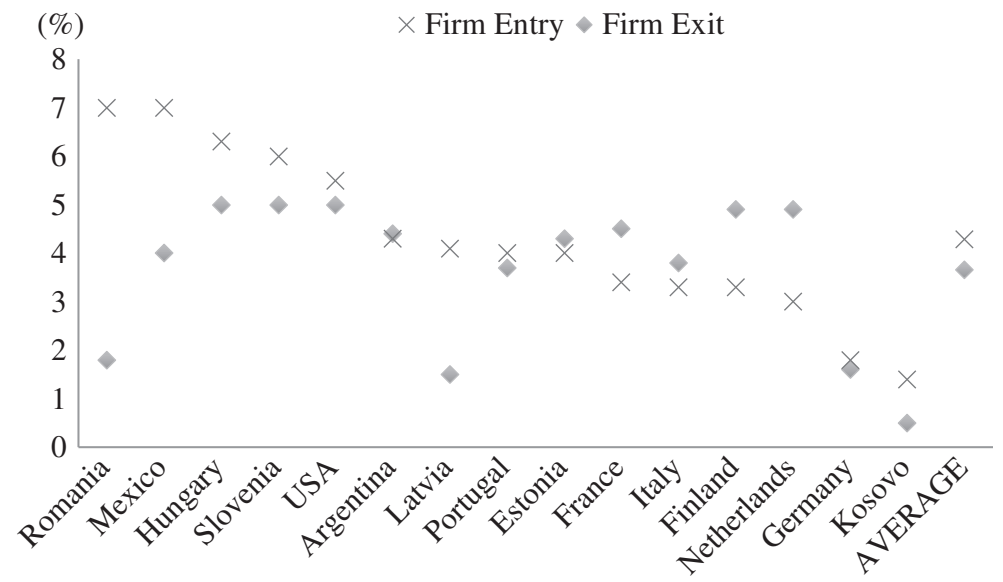

Source: Authors' calculations using data from KBRA for Kosovo, and Bartelsman, Haltiwanger, and Scarpetta (2009) for all other countries. Countries are sorted in descending order by firm entry. AVERAGE is the simple average. 
Fig. 3. Firm Survival at Different Lifetimes (Ages 2 and 4)

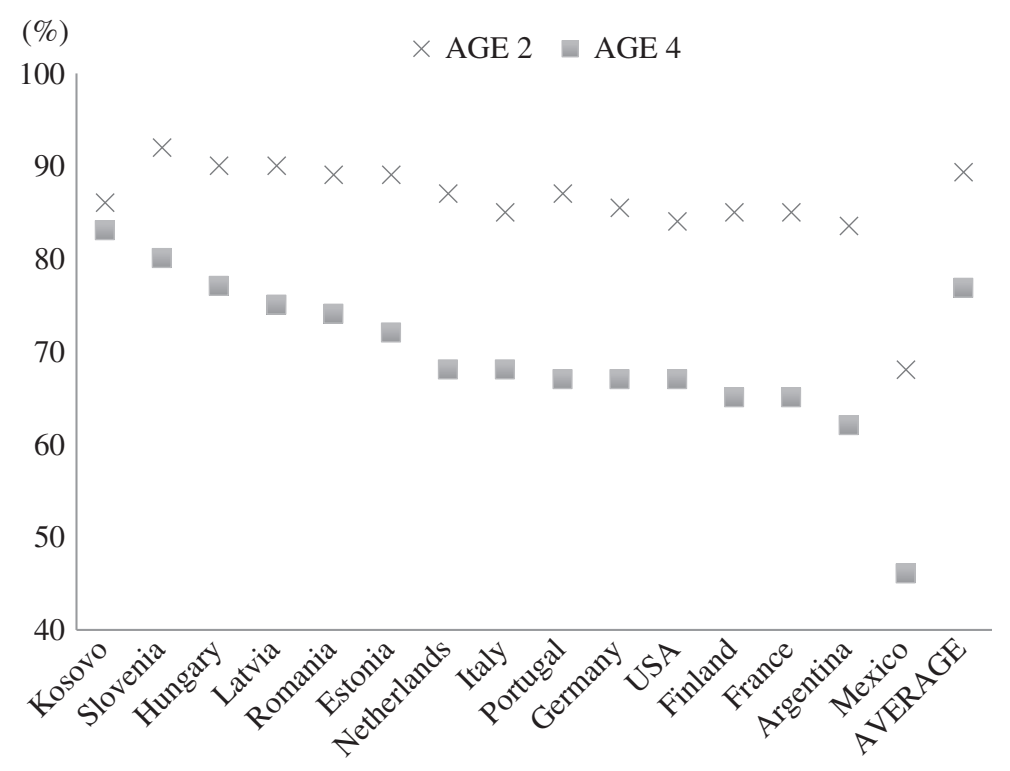

Source: Authors' calculations using data from KBRA for Kosovo, and Bartelsman, Haltiwanger, and Scarpetta (2009) for all other countries. Countries are sorted in descending order by survival rates at age 4. AVERAGE is the simple average.

Figure 3 depicts survival rates at ages two and four. The share of new firms surviving beyond the first two years in Kosovo is similar to that in other countries (except for Mexico). Yet, a distinctive feature of Kosovo is the large share of firms that survive beyond four years. About $83 \%$ of firms survive after four years, with this figure falling to $70 \%-80 \%$ in other less-developed economies, and $60 \%-70 \%$ in developed economies. This may suggest that market selection forces are less harsh in Kosovo than in other countries.

\section{B. Survival Analysis of Newborn Firms in Kosovo}

This section presents the results of both the nonparametric and multivariate regression analysis.

Table 1 displays descriptive statistics and the results from the nonparametric survival analysis. The analysis is based on 40,069 newborn firms over the period 2008-12. Of these, 6,521 firms had failed by the end of 2013. Column (8) shows that most newborn firms are very small (70.9\% have one employee, and $27.1 \%$ between two and five employess), of sole proprietor-ownership type (84.6\%), in the service sector (80.1\%), and mainly located in Prishtina and Gjilan (57.5\%). 


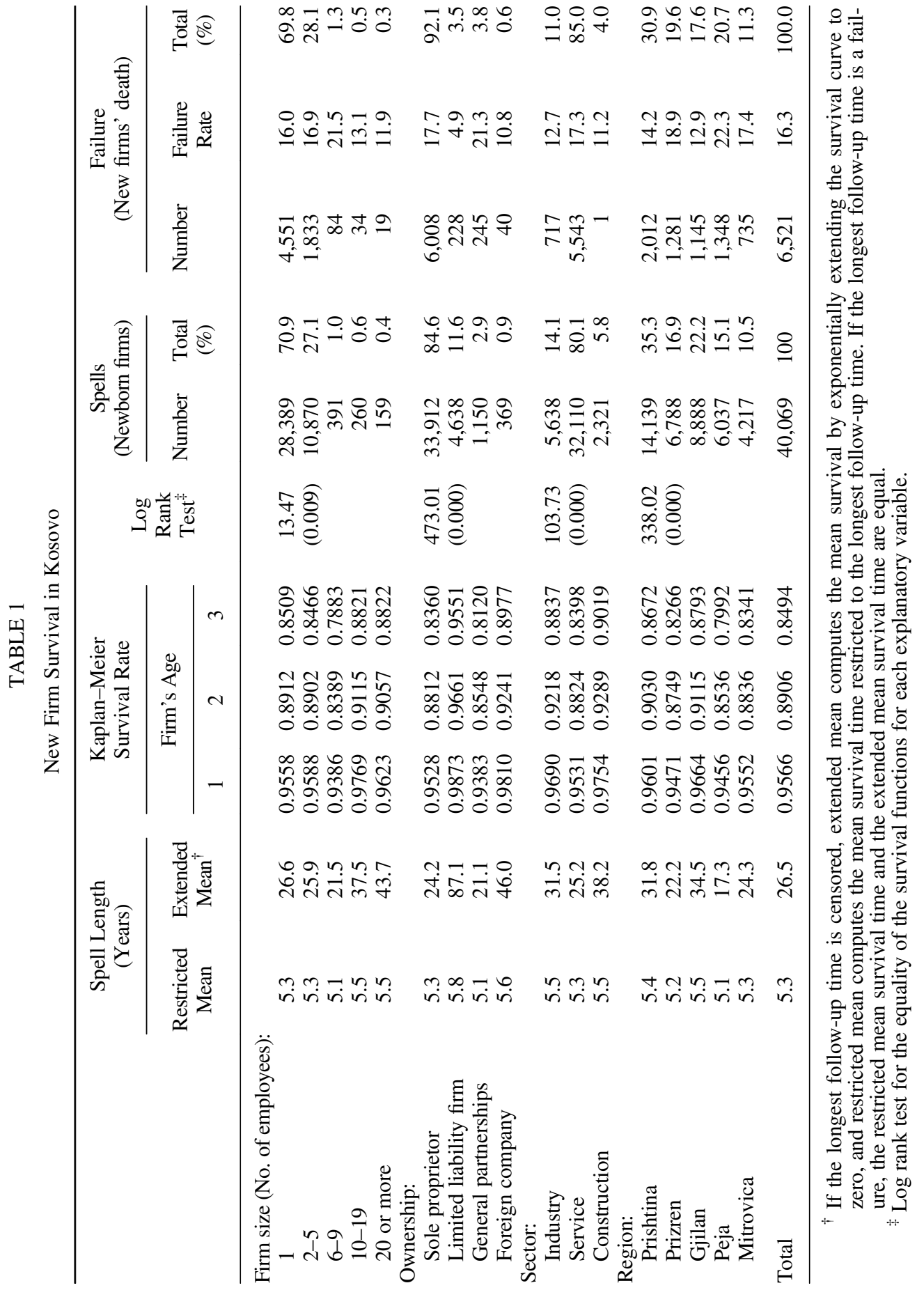


Columns (3)-(5) and (10) show that the chances of survival of newborn companies in Kosovo are remarkably high, which may suggest some distinctive features of Kosovo that we will discuss below. The log-rank tests (column 6) confirm statistically significant differences in the effect of each explanatory variable on survival. Without controlling for the effect of other variables, larger, limited liability companies enjoy better survival prospects (columns 1-6 and 8). Likewise, new firms in the construction sector and located in either Prishtina or Gjilan survive longer.

Table 2 presents the results of the estimation of three reduced-form models. These models show the relationship between each explanatory variable and the hazard rate once we control for the impact of other variables. Column (1) reports the results of a semiparametric Cox proportional hazards model (equation 2). Columns (2)-(3) show the results for a cloglog model with no unobserved heterogeneity and including unobserved heterogeneity, respectively (equation 3).

Before turning to the results, some comments on model specification and coefficient interpretation are in order. First, we estimate frailty survival models (column 3) to control for firm-level unobserved heterogeneity (related to unobserved firm organizational capabilities, access to specific assets, etc.). We cannot reject the null hypothesis of no unobserved individual heterogeneity at a $1 \%$ significance level. Hence, the non-frailty models (columns 1 and 2) are our preferred models. Second, the Cox model is used as a benchmark, while the cloglog model with no frailty is our preferred specification given that it allows both accounting for the discreteness of the data and estimating the pattern of duration dependence (i.e., age effects). Third, the reported coefficients are hazard ratios. Therefore, a unit change in a variable leads to a proportional shift in the conditional probability of exit. A hazard ratio smaller (greater) than one means a negative (positive) effect of the explanatory variable on the hazard rate. That is, it decreases (increases) the hazard rate, increasing (decreasing) survival. Fourth, the covariates are included as a set of dummy variables to facilitate interpretation and also to account for possible nonlinearities in their effects.

Interestingly, the results in column (2) reveal an inverted U-shaped relationship between the hazard rate and firm age and firm size. The hazard rate reaches a peak in the second year of a firm's lifetime, decreasing thereafter. ${ }^{6}$ Our results are compatible with the liability of "adolescence" hypothesis (Bruderl and Schussler 1990; Fichman and Levinthal 1991). That is, new organizations can survive for a while by drawing on their initial endowments. Then, failure rates reach a peak with the exhaustion of these endowments. They then decrease, with only the fittest firms surviving. As for size, the risk of failure is the lowest for one-employee firms and large firms (more than nine employees), with no

\footnotetext{
6 The hazard rate for firms aged one and three is not statistically different.
} 
TABLE 2

New Firm Survival in Kosovo: Regression Analysis

\begin{tabular}{|c|c|c|c|}
\hline $\begin{array}{l}\text { Dependent Variable: } \\
\text { Hazard Rate }\end{array}$ & $\begin{array}{c}{[1]} \\
\text { Cox Proportional } \\
\text { Hazards Model }\end{array}$ & $\begin{array}{c}{[2]} \\
\text { Cloglog Model (Discrete- } \\
\text { time equiv. to [1]) }\end{array}$ & $\begin{array}{c}{[3]} \\
\text { Cloglog Frailty } \\
\text { Model }\end{array}$ \\
\hline \multicolumn{4}{|c|}{ Firm size (One employee omitted): } \\
\hline \multirow[t]{2}{*}{$2-5$} & $1.09 * * *$ & $1.10^{* * *}$ & $1.10 * * *$ \\
\hline & [0.0308] & [0.0312] & [0.0309] \\
\hline \multirow[t]{2}{*}{$6-9$} & $1.46 * * *$ & $1.48 * * *$ & $1.48 * * *$ \\
\hline & {$[0.1610]$} & {$[0.1634]$} & {$[0.1638]$} \\
\hline \multirow[t]{2}{*}{$10-19$} & 0.85 & 0.85 & 0.85 \\
\hline & [0.1463] & [0.1458] & [0.1458] \\
\hline \multirow[t]{2}{*}{20 or more } & 0.81 & 0.80 & 0.80 \\
\hline & {$[0.1866]$} & {$[0.1859]$} & {$[0.1846]$} \\
\hline \multicolumn{4}{|c|}{ Ownership (Limited liability omitted): } \\
\hline \multirow[t]{2}{*}{ Sole proprietor } & $3.67 * * *$ & $3.75 * * *$ & $3.75 * * *$ \\
\hline & {$[0.2473]$} & {$[0.2530]$} & {$[0.2532]$} \\
\hline \multirow{2}{*}{ General partnerships } & $4.24 * * *$ & $4.36 * * *$ & $4.36 * * *$ \\
\hline & [0.3905] & [0.4024] & [0.4021] \\
\hline \multirow[t]{2}{*}{ Foreign company } & $2.09 * * *$ & $2.11 * * *$ & $2.11 * * *$ \\
\hline & {$[0.3576]$} & {$[0.3614]$} & [0.3611] \\
\hline \multicolumn{4}{|l|}{ Sector (Industry omitted): } \\
\hline \multirow[t]{2}{*}{ Service } & $1.39 * * *$ & $1.41 * * *$ & $1.41 * * *$ \\
\hline & [0.0558] & {$[0.0572]$} & [0.0566] \\
\hline \multirow[t]{2}{*}{ Construction } & $0.87 * *$ & $0.87 * *$ & $0.87 * * *$ \\
\hline & [0.0628] & [0.0627] & [0.0628] \\
\hline \multicolumn{4}{|c|}{ Region (Prishtina omitted): } \\
\hline \multirow[t]{2}{*}{ Prizren } & $1.40 * * *$ & $1.41 * * *$ & $1.41 * * *$ \\
\hline & [0.0501] & [0.0509] & [0.0506] \\
\hline \multirow[t]{2}{*}{ Gjilan } & $0.92 * *$ & $0.92 * *$ & $0.92 * *$ \\
\hline & [0.0342] & [0.0342] & [0.0342] \\
\hline \multirow[t]{2}{*}{ Peja } & $1.66^{* * * *}$ & $1.69 * * *$ & $1.69 * * *$ \\
\hline & [0.0586] & [0.0598] & [0.0596] \\
\hline \multirow[t]{2}{*}{ Mitrovica } & $1.30 * * *$ & $1.31 * * *$ & $1.31 * * *$ \\
\hline & {$[0.0561]$} & {$[0.0568]$} & {$[0.0566]$} \\
\hline \multicolumn{4}{|c|}{ Year dummies (Year 2008 omitted): } \\
\hline \multirow[t]{2}{*}{ Year 2009} & $1.27 * * *$ & $1.28 * * *$ & $1.28 * * *$ \\
\hline & [0.0924] & [0.0921] & [0.0928] \\
\hline \multirow[t]{2}{*}{ Year 2010} & $1.18 * *$ & $1.18 * *$ & $1.18 * *$ \\
\hline & {$[0.0841]$} & {$[0.0852]$} & {$[0.0843]$} \\
\hline \multirow[t]{2}{*}{ Year 2011} & $1.30 * * *$ & $1.31 * * *$ & $1.31 * * *$ \\
\hline & [0.0920] & [0.0927] & [0.0925] \\
\hline \multirow[t]{2}{*}{ Year 2012} & $1.21 * * *$ & $1.21 * * *$ & $1.21 * * *$ \\
\hline & [0.0848] & [0.0845] & {$[0.0850]$} \\
\hline \multirow[t]{2}{*}{ Year 2013} & $1.31 * * *$ & $1.31 * * *$ & $1.31 * * *$ \\
\hline & [0.0972] & [0.0975] & [0.0975] \\
\hline
\end{tabular}


TABLE 2 (Continued)

\begin{tabular}{|c|c|c|c|}
\hline $\begin{array}{l}\text { Dependent Variable: } \\
\text { Hazard Rate }\end{array}$ & $\begin{array}{c}{[1]} \\
\text { Cox Proportional } \\
\text { Hazards Model }\end{array}$ & $\begin{array}{c}{[2]} \\
\text { Cloglog Model (Discrete- } \\
\text { time equiv. to [1]) }\end{array}$ & $\begin{array}{c}{[3]} \\
\text { Cloglog Frailty } \\
\text { Model }\end{array}$ \\
\hline \multicolumn{4}{|l|}{ Firm age (Dummies): } \\
\hline One year old & & $\begin{array}{l}0.007 * * * \\
{[0.0007]}\end{array}$ & $\begin{array}{l}0.007 * * * \\
{[0.0007]}\end{array}$ \\
\hline Two years old & & $\begin{array}{l}0.010^{* * * *} \\
{[0.0011]}\end{array}$ & $\begin{array}{l}0.010^{* * * *} \\
{[0.0011]}\end{array}$ \\
\hline Three years old & & $\begin{array}{l}0.007 * * * \\
{[0.0007]}\end{array}$ & $\begin{array}{l}0.007 * * * \\
{[0.0007]}\end{array}$ \\
\hline Four years old & & $\begin{array}{l}0.004 * * * \\
{[0.0005]}\end{array}$ & $\begin{array}{l}0.004 * * * \\
{[0.0005]}\end{array}$ \\
\hline Five years old & & $\begin{array}{l}0.003 * * * \\
{[0.0004]}\end{array}$ & \\
\hline Six years old & & $\begin{array}{l}0.002 * * * \\
{[0.0003]}\end{array}$ & $\begin{array}{l}0.002 * * * \\
{[0.0003]}\end{array}$ \\
\hline Log likelihood & $-67,109.53$ & $-25,452.86$ & $-25,452.86$ \\
\hline No. of firms & 40,069 & 40,069 & 40,069 \\
\hline No. of observations & 142,846 & 142,846 & 142,846 \\
\hline
\end{tabular}

Note: Robust standard errors are in brackets; $p$-values are calculated using robust standard errors.

${ }^{* * *} p<0.01 ; * * p<0.05 ; * p<0.10$.

statistically significant differences between them. Firms with two to nine employees face higher risk, especially for firms with six to nine employees. The high survival rate of one-employee firms is not in line with previous findings (Geroski, Mata, and Portugal 2010) and could be a distinctive feature of Kosovo that will be discussed in the next section.

In addition, once we control for other factors, limited liability firms face a much lower exit risk than new firms with other legal and ownership structures, including foreign-owned companies. The risk is substantially higher for sole proprietor and general partnerships and lower among limited liability new firms. Furthermore, we find important differences in survival rates across sectors, as previously reported by other papers (Audretsch and Mahmood 1994; Mata and Portugal 1994). We find that the hazard rate is lower in the construction sector than in industry and services. Our findings are probably related to demand factors given the reconstruction phase that Kosovo has been undergoing since 1999.

Our results also suggest that the regions where firms are born affect their survival chances. ${ }^{7}$ The lowest failure risk is for firms created in Gjilan and Prishtina,

7 Kosovo currently includes five regions that are located east (Gjilan and Prishtina), south (Prizren), west (Peja), and north (Mitrovica). The eastern region is most populated, while the western and northern regions are least populated. 
whereas it is highest in Mitrovica, Prizren, and especially in Peja. Therefore, firms have a higher chance of survival if they are located in the most populated areas. Previous studies (Fotopoulos and Louri 2000) also report better survival chances for firms located near metropolitan areas. Finally, the set of year dummies accounts for the evolution of the risk of firm failure over time that is common to all existing firms in a particular year. These variables capture the stance of the business cycle. The results in Table 2 clearly indicate that firms born in 2008 enjoy better survival prospects than firms born later.

\section{DISCUSSION AND CONCLUSIONS}

This paper examines newborn firm survival and firm turnover in Kosovo using survival analysis. The data comprise the population of firms newly born in 2008-12 and followed until the end of 2013. This analysis is complemented with a comparison of firm churning in Kosovo with that in other developed and developing countries. This topic is particularly interesting for a relatively poor economy given that firm birth, survival, and growth are crucial for boosting productivity, employment opportunities, and economic growth.

The results unravel some distinctive features of Kosovo. First, entry rates, especially of large firms, are lower than those in other developing countries. Second, exit rates are very low, and lead to high survival rates. Hence, firm turnover is relatively low. Third, failure rates for one-employee firms and for large firms (i.e., those with more than 10 employees) are fairly low and not significantly different.

Rather tentatively, we argue that these findings are related to some particular features of Kosovo that explain the relatively mild selection process. The high incidence of one-employee firm entry together with high survival rates is compatible with two nonexclusive explanations. First, low income and high unemployment may "push people into entrepreneurship" and make them "fight" harder to survive, increasing their expected lifetimes (Berner, Gomez, and Knorringa 2012). Second, constraints to economic activity (i.e., barriers to firm entry and exit) and uncertainty are important in Kosovo. High sunk entry costs become high barriers to exit when reentry is possible. These factors may help explain low entry and exit rates and high survival as well as small-size entry in the context of high uncertainty. In this context, new-firm entry is driven by a search process: firms make small commitments to determine their fitness to survive. Large-scale entry is less common as it faces high entry barriers and involves large commitments given the small market size.

Recent studies (Sahiti and Smith 2017; Hashi and Krasniqi 2011; Sen and Kirkpatrick 2009; Klapper et al. 2007) refer to the limited rule of law, poor law enforcement, unfair competition, high level of corruption and crime, high cost of 
finance, poor quality of infrastructure, and poor availability of human capital as factors that may hinder firm entry, exit, and growth. With regard to human capital, a recent study (OECD 2013) concludes that the higher education system in Kosovo has not succeeded in promoting entrepreneurship, and hence underperforming Western Balkan countries.

This paper has several implications for policymakers. In particular, our results suggest that besides the improvement of physical infrastructure, it is essential to improve the functioning of market selection forces. The adequate enforcement of laws and regulations to protect investors, the improvement of the financial system, and the improvement of the education system may have a very high payoff in terms of business dynamics, productivity, and economic growth.

\section{REFERENCES}

Ahn, Sanghoon. 2001. "Firm Dynamics and Productivity Growth: A Review of Micro Evidence from OECD Countries." OECD Economics Department Working Papers no. 297. Paris: OECD Publishing.

Alam, Asad; Paloma Anós Casero; Faruk Khan; and Charles Udomsaph. 2008. Unleashing Prosperity: Productivity Growth in Eastern Europe and the Former Soviet Union. Washington, DC: World Bank.

Audretsch, David B., and Talat Mahmood. 1994. "The Rate of Hazard Confronting New Firms and Plants in U.S. Manufacturing." Review of Industrial Organization 9, no. 1: 41-56.

Bartelsman, Eric; John Haltiwanger; and Stefano Scarpetta. 2009. "Measuring and Analyzing Cross-Country Differences in Firm Dynamics." In Producer Dynamics: New Evidence from Micro Data, edited by Timothy Dunne, J. Bradford Jensen, and Mark J. Roberts. Chicago: University of Chicago Press.

Berglund, Elisabet, and Kurt Brännäs. 2001. "Plants' Entry and Exit in Swedish Municipalities." Annals of Regional Science 35, no. 3: 431-48.

Berner, Erhard; Georgina Gomez; and Peter Knorringa. 2012. "Helping a Large Number of People Becoming a Little Less Poor: The Logic of Survival Entrepreneurs." European Journal of Development Research 24, no. 3: 382-96.

Bruderl, Josef, and Rudolf Schussler. 1990. "Organizational Mortality: The Liabilities of Newness and Adolescence.” Administrative Science Quarterly 35, no. 3: 530-47.

Cox, David R. 1975. "Partial Likelihood." Biometrika 62, no. 2: 269-76.

Dunne, Timothy; Shawn D. Klimek; and Marke J. Roberts. 2005. "Exit from Regional Manufacturing Markets: The Role of Entrant Experience." International Journal of Industrial Organization 23, nos. 5-6: 399-421.

Dunne, Timothy; Mark J. Roberts; and Larry Samuelson. 1988. "Patterns of Firm Entry and Exit in U.S. Manufacturing Industries." Rand Journal of Economics 19, no. 4: 495-515.

Fichman, Mark, and Daniel A. Levinthal. 1991. "Honeymoons and the Liability of Adolescence: A New Perspective on Duration Dependence in Social and Organizational Relationships." Academy of Management Review 16, no. 2: 442-68. 
Fotopoulos, Georgios, and Helen Louri. 2000. "Location and Survival of New Entry." Small Business Economics 14, no. 4: 311-21.

Geroski, Paul A. 1995. "What Do We Know about Entry?" International Journal of Industrial Organization 13, no. 4: 421-40.

Geroski, Paul A.; José Mata; and Pedro Portugal. 2010. "Founding Conditions and the Survival of New Firms." Strategic Management Journal 31, no. 5: 510-29.

Hashi, Iraj, and Besnik A. Krasniqi. 2011. "Entrepreneurship and SME Growth: Evidence from Advanced and Laggard Transition Economies." International Journal of Entrepreneurial Behavior \& Research 17, no. 5: 456-87.

Hosmer, David W., and Stanley Lemeshow. 1999. Applied Survival Analysis: Regression Modeling of Time to Event Data. New York: Wiley.

Jenkins, Stephen P. 2005. "Survival Analysis." Unpublished manuscript (consulted April 19, 2019).

Klapper, Leora; Raphael Amit; Mauro F. Guillén; and Juan M. Quesada. 2007. "Entrepreneurship and Firm Formation across Countries." Policy Research Working Paper no. 4313. Washington, DC: World Bank.

Klapper, Leora, and Christine Richmond. 2011. "Patterns of Business Creation, Survival and Growth: Evidence from Africa." Labour Economics 18, Suppl. 1: 32-44.

Mata, José, and Pedro Portugal. 1994. "Life Duration of New Firms." Journal of Industrial Economics 42, no. 3: 227-46.

- 2002. "The Survival of New Domestic and Foreign-Owned Firms." Strategic Management Journal 23, no. 4: 323-43.

Organisation for Economic Co-operation and Development (OECD). 2013. Assessment of the Kosovo Innovation System. Paris: OECD.

Prentice, R. L., and L. A. Gloeckler. 1978. "Regression Analysis of Grouped Survival Data with Application to Breast Cancer Data." Biometrics 34, no. 1: 57-67.

Sahiti, Fadil, and Helen L. Smith. 2017. "An Application of Growth Diagnostics on the Growth of Firms: With Evidence from Kosovo Firms." Journal of Innovation and Entrepreneurship 6, no. 1, Article 16. https://doi.org/10.1186/s13731-017-0078-8.

Scarpetta, Stefano; Philip Hemmings; Thierry Tressel; and Jaejoon Woo. 2002. "The Role of Policy and Institutions for Productivity and Firm Dynamics: Evidence from Micro and Industry Data." OECD Economics Department Working Papers no. 329. Paris: OECD Publishing.

Sen, Kunal, and Colin Kirkpatrick. 2009. "A Diagnostics Approach to Economic Growth and Employment Policy in Low Income Economies: The Case of Kosovo." Journal of International Development 23, no. 1: 132-54.

Stiglitz, Joseph E., and Andrew Weiss. 1981. "Credit Rationing in Markets with Imperfect Information." American Economic Review 71, no. 3: 393-410.

Stinchcombe, Arthur L. 1965. "Social Structure and Organizations." In Handbook of Organizations, edited by James G. March. Chicago: Rand McNally. 


\section{APPENDIX}

Country classification according to income levels follows World Bank guidelines. As of July 1, 2013, the income classification by GNI per capita are as follows:

1. Low income: US $\$ 1,035$ or less

2. Lower middle income: US $\$ 1,036$ to US $\$ 4,085$

3. Upper middle income: US $\$ 4,086$ to US $\$ 12,615$

4. High income: US\$12,616 or more

The data on income levels follow Bartelsman, Haltiwanger, and Scarpetta's (2009) study on the period when the countries' data on firm dynamics was extracted. Therefore, all countries, except for Kosovo, are classified according to data for the period 1995-2003. Data for Kosovo correspond to the period 2010-14.

High-income countries: The United States, the Netherlands, Finland, Germany, France, Italy, and Portugal.

Upper-middle-income countries: Slovenia, Argentina, Hungary, Mexico, and Estonia.

Lower-middle-income countries: Latvia, Romania, and Kosovo. 